УДК 343.2/.7(510)

\title{
Formation of the Basic Principles in the Modern Chinese Criminal Law
}

\author{
Pang Dongmei ${ }^{\text {a* }}$ and Gao Mingxuan ${ }^{\mathrm{b}}$ \\ ${ }^{a}$ Heilongjiang University \\ 74 Xuefu Road, Nangang District, Harbin, \\ 150080, Heilongjiang province, P. R. China \\ ${ }^{b}$ Beijing Normal University
}

No. 19, XinJieKouWai Str., HaiDian District, Beijing 100875, P. R. China

Received 28.04.2016, received in revised form 22.06.2016, accepted 05.08.2016

The Articles 3, 4, 5 of the 1997 Criminal Code of the People's Republic of China (hereinafter - 1997 PRC Criminal Code) provide for the principle of legality, the principle of equality of citizens before the law and the principle of compliance of punishment with crime and criminal liability respectively. These three articles are the legislative innovations for the 1997 PRC Criminal Code. Formation of the basic principles of criminal law is considered to be one of the main problems of the criminal legislation, so in the development of drafts of the Criminal Code in legislative and judicial bodies, as well as among experts there were different views on whether it is necessary to additionally provide for the basic principles in the Criminal Code of China, on which basic principles should be added, how and what chapter in the Criminal Code should describe these basic principles, etc. All these issues and ways of their solution are presented in this article.

Keywords: principles of criminal law; principle of legality; principle of equality of citizens before the law; principle of compliance of punishment with crime and criminal justice.

This article was prepared within the framework of the key project of the National Natural Science Foundation of China "Study of institutions in the General part of criminal law" (project number: 16AFX008).

DOI: 10.17516/1997-1370-2016-9-10-2465-2474.

Research area: law.

Legal principles as the basis of legal norms reflect people's understanding and perception of the basic regularity in the laws, besides they contain the legislative value commitment, the basic spirit and the direction of law enforcement interests. The current 1997 Criminal Code of the
PRC has enshrined such basic principles as the principle of legality, the principle of equality of citizens before the law, the principle of compliance of punishment with crime and criminal liability. As a rule, a criterion for establishing these basic principles in the current Chinese criminal law

(C) Siberian Federal University. All rights reserved

* Corresponding author E-mail address: pangdongmei71@163.com; pangnajia@mail.ru 
is recognized that: 1) all of these principles are characteristic of the criminal law, but it does not exclude the presence of the same principle existing in other branch laws; 2) These three basic principles that run like a golden thread through the fabric of the criminal law as a whole are the basis for all of its rules, determine the content of both the criminal law in general and its individual institutions (Fen Fenglin, 1999). All these three basic principles are equally functioning as fundamental principles. Despite the fact that at the present time these three principles are considered to be generally recognized, in the development of the draft 1997 Chinese Criminal Code there was a hot debate on the need to create basic criminal law principles in the new Criminal Code.

\section{The principle of legality} (Article 3 of the 1997 PRC Criminal Code)

As is known, the Art. 3 of the 1997 PRC Criminal Code established the principle of legality: "If the law clearly defines the act as criminal, it is defined as a crime and shall be punished in accordance with the law; if the law has not a clear definition of the act as a crime, it is not classified as a crime and shall not be punished."

Among the three main principles included in the 1997 PRC Criminal Code the principle of legality is recognized as the most important principle provided for in the legislation of many countries, which fully reflects the modern legal spirit and the development of democracy. In the previous 1979 PRC Criminal Code due to the influence of legal ideas about the "lack of desire for absolute precision", the wordings were vague in many articles. Also, it was possible to apply the criminal law by analogy, and the special criminal laws contained the rule of a retroactive effect of laws with a more severe punishment. Consequently, the principle of legality in the
1979 PRC Criminal Code failed to be realized completely. The state of the legislation of that time not only hampered the China criminal legislation's implementation of the human rights protection function, but also, to some extent, negatively affected the image of China in the eyes of the international community.

In fact, the understanding of the need to include the principle of legality in the PRC Criminal Code and disadvantages of application of the criminal law by analogy have long been present among the Chinese specialists in the field of criminal law after the adoption of the 1979 PRC Criminal Code. Furthermore, along with the Chinese legislature's inclusion of development of amendments to the Criminal Code in the legislative program, this understanding becomes deeper and more comprehensive. However, analyzing the process of the development of amendments to the PRC Criminal Code, it can be seen that the path of the inclusion of the principle of legality in the Criminal Code was not smooth, but winding. Meanwhile, around this issue, the developers of the draft Criminal Code spoiled a lot of version, and confrontation of different points of view reached the extreme bitterness at times.

For quite a long time after the comprehensive revision of the criminal law was officially included in the national legislative programme, among professionals in the field of criminal law there were different views on the establishment of the principle of legality and the abolition of analogy. Speaking about the inclusion of the principle of legality in the Criminal Code, the opponents argued that the very principle of legality requires that the legislative body preliminary provides for all the crimes and punishments in the Criminal Code, which contradicts the materialist theory of knowledge; implementation of the principle of legality would limit judicial practice, interfere with consideration of the criminal cases on 
crimes of new kinds and a tough fight against crimes; in this regard, they considered that the principle of legality should not be recognized as the basic principle of the PRC Criminal Code. Supporters, on the other hand, pointed out that the new Criminal Code should expressly provide for the principle of legality (Gao Mingxuan, 1995; Ma Kechang, 1997). Their main reasons were as follows:

a. Preservation and consolidation of the principle of legality in the Criminal Code of our country clearly indicate that China is a state governed by the rule of law, can keep pace with the international progress and integrate into the international legal framework. It will also help to improve the image of the Chinese criminal law in the eyes of the international community and enhance the authority of the Chinese criminal law and the rule of law in general.

b. The greatest value of the principle of legality is prevention of the arbitrary classification of crime and protection of human rights. The establishment of the principle of legality in the Criminal Code may have a slight negative impact: in the future, the judicial bodies will not be able to punish for a socially dangerous act, which is not provided for in the PRC Criminal Code. This problem occurs in all countries where the principle of legality is applied. Gaps and the backlog of legislation should be compensated for by the improvement of the criminal legislation itself, and not by the analogy of law. The absence of the principle of legality in the PRC Criminal Code will lead to a lack of people's faith in laws and to such a dangerous consequence as suspicion that the Criminal Code contains the factors of legality destruction. In turn, although with the full implementation of the principle of legality the inevitable gaps in the Criminal Code could lead to the fact that some of the missing-in-law socially dangerous acts will become unpunished, but compared to the prejudice to the rights and freedoms of citizens and the democratic concept of socialism caused by analogy of the law it is minor flaw. Thus, it is vigorously advisable to implement the principle of legality.

c. According to the supporters of the immediate abolition of analogy, the principle of legality and the institute of analogy, in fact, contradict each other, therefore, implementation of the principle of legality requires to cancel the institute of analogy and to directly incorporate the principle of legality in the Code.

At the time there were also the opposing views on the issue of exclusion of the analogy of legality from the PRC Criminal Code (Zhao Bingzhi, 2004):

a. According to supporters of the preservation of analogy of the law, the development of detailed, improved Criminal Code is not practical, and the preservation of the institute of analogy, on one hand, will help to avoid legal leapfrog and, on the other hand, will help to gain experience for further development of the Criminal Code and amendments to it. Therefore, the preservation of the institute of analogy of the law in the Criminal Code is necessary.

b. From the point of view of the supporters of temporary preservation of analogy, this institute has a positive value in the conditions of the lack of legislative experience and inadequate legislation, but after creation of the relevant conditions and consolidation of the principle of legality in the Code the analogy should be abolished.

It should be noted that at the time the dominant position approved by the majority of participants in the discussion was the temporary preservation rather than the immediate abolition of analogy. The highest legislative body at the time was also prone to the "temporary preservation" of the institution. Consequently, the Art. 85 of the draft PRC Criminal Code dated November 16, 1988 not only preserved the former institute of analogy in the 1979 PRC Criminal Code, 
but also mitigated the procedural conditions of application of analogy: not every criminal case with the analogy should be submitted for approval by the Supreme People's Court, and cases with the analogy approved by the Supreme People's Court were to be considered as exemplary cases for the courts at all levels. Nevertheless, most scholars and practitioners working in the field of criminal law objected to the content of the Draft. In this regard, in the Draft Criminal Code of PRC dated December 25, 1988 the provisions on liberalization of the use of analogy have been corrected. However, given the prevailing point of view at the time, the institute of analogy has been preserved. In this connection, in the drafts of PRC Criminal Code for September dated November 16 and December 25, 1988, the principle of legality was not provided for and, accordingly, analogy was admitted in the General Part of the Criminal Code.

With an in-depth discussion on amendments to the PRC Criminal Code, as well as with political and economic changes and ongoing development of the criminal law in our country, the above three views on preservation or abolition of the institute of analogy were gradually reduced to two positions: full preservation or immediate abolition of analogy. On April 30, 1996, the Legal Affairs Committee of the Standing Committee of the National People's Congress organized a special symposium in Beijing to make amendments to the Criminal Code, which was attended by about 60 experts and scholars from the legislative and judicial bodies, research institutions and various universities. Gao Shijiang who at the time worked as deputy chairman of the Legal Affairs Committee of the NPC Standing Committee put forward ten major problems in the development of amendments to the Criminal Code: first of all it was the establishment of the principle of legality and the abolition of analogy. Accordingly, the Supreme People's Court, Supreme People's
Procuratorate and Ministry of Public Security of China have discussed these ten problems and submitted written comments.

According to the Ministry of Public Security, the establishment of the principle of legality is very important for strict execution of the law and protection of the legitimate rights and interests of citizens. However, since the criminal law serves as a means of combating crime, it is necessary to proceed from reality in the fight against criminality and the need to combat crimes in establishing the basic principles of the Criminal Code. In addition, in our country that is at the stage of the economic reform and the establishment of the socialist market economy, due to improper functioning of different economic management systems, the existence of some problems in the system of public distribution, as well as the corrosive influence of capitalist ideas, entering of foreign criminal groups, there is a growth trend in the number of criminal offenses, new kinds of crimes are constantly occurring, so that some of them cannot be foreseen at the time of lawmaking. Since the establishment of the principle of legality in the Criminal Code means the need to abolish the institute of analogy, in the process of drafting the current Criminal Code with consolidation of the principle of legality, the realities of the fight against crime should be fully taken into account, the scope of socially dangerous acts as crimes should be seriously analyzed and clearly defined, so that the law-making activity could be designed for the future, could avoid gaps and not condone criminal acts. If this cannot be achieved, we should have a think if the immediate abolition of the institute of analogy is rational (Abstracts of the consolidated report, 1998).

Conclusions of the Supreme People's Court and the Supreme People's Procuratorate were distinct and identical: the General Part of the Criminal Code should expressly provide for the principle of legality and abolish the analogy. 
It can be said that the position of the highest judicial and supervisory bodies corresponded to the prevailing point of view among the Chinese scientists and experts in the field of criminal law. In fact, within more than ten years after the adoption of the 1979 PRC Criminal Code, the supreme legislative body has developed 24 separate criminal laws, settled rules concerning the imposition of criminal liability in 107 non-criminal laws and introduced significant amendments to the Criminal Code: more than 130 crime components have been added, which exceeds the number of crime components initially provided for in the 1979 PRC Criminal Code. The number of crimes included a variety of socially dangerous acts, especially in the socio-economic sphere. It can be said that the current Criminal Code is quite perfect and circumspect and provides for all the basic criminal acts. In this connection, it no longer makes sense to preserve the institute of analogy in the Criminal Code taking into account that within more than ten years after the adoption of the 1979 PRC Criminal Code the percentage of cases with the institute of analogy in judicial practice was small. With these considerations in mind the Draft General Part of the PRC Criminal Code dated August 8, 1995 developed by the Legal Affairs Committee of the NPC Standing Committee, abolished the rule of analogy, while the Art. 3 of the PRC Criminal Code provided for the principle of legality for the first time: if the law does not have a clear definition of a committed act as a crime, it is not classified as a crime and is not punishable. It appears that this revision of the Criminal Code laid the foundation for the abolition of the institute of analogy and consolidation of the principle of legality in the 1979 Criminal Code of the PRC. All subsequent drafts of the Criminal Code without exception provided for the principle of legality and abolished analogy.
In the Draft of the General Part of the Criminal Code dated August 8, 1995, the principle of legality was established in the Art. 3 of Chapter 1 "Objectives, Principles and Jurisdiction" of the General Part of the Criminal Code. In the following drafts of the General Part of the Criminal Code, as well as in the Draft Criminal Code dated August 31, 1996, a place of the principle of legality in the PRC Criminal Code has not been changed. However, in the Draft (a version for discussion) dated October 10, 1996, a legislator has changed the title of Chapter 1 of the General Part of the Criminal Code to "Objectives and Jurisdiction of the Criminal Code" and removed the word "principles" transferring the principle of legality to the Art. 11 of Chapter 2 "Crime" of the General Part of the Criminal Code.

Further, during the discussion of the above Draft, theorists and practitioners in the field of criminal law pointed out that the basic principles of the Criminal Code are recognized by guidelines that permeate all the criminal law standards and their application, reveal basic features of the criminal law and its basic spirit and play a dominant and central role in the Criminal Code (Fang Chengxia, 1999). The described status determines the need for including these principles in the first chapter of the Criminal Code. It is unacceptable that the principle of legality penetrating the entire criminal legislation and criminal justice is set out in paragraph 1 "Crime and criminal liability" of Chapter 2 of the General Part of the Criminal Code. Only concentration of the basic principles in Chapter 1 of the General Part of the Criminal Code can fully ensure the fundamental status of these principles in the Criminal Code and the guiding value in relation to the criminal law and justice. The legislative body eventually accepted this proposal. Accordingly, in the Draft of mid-December 1996 and in further drafts, the principle of legality was restored in Art. 3 of Chapter 1 "Objectives, Basic Principles 
and Jurisdiction of the Criminal Code" of the General Part of the Criminal Code.

When considering amendments to the Criminal Code, the legislative consolidation of the principle of legality has undergone changes: when in Art. 3 of the Draft General Part of the Criminal Code dated August 8, 1995 the principle of legality was firstly provided for, the law development bodies adopted the following wording: "if the law does not have a clear definition of a committed act as a crime, it is not classified as a crime and shall not be punished". This wording is fully consistent with the traditional notion in the classical sense. Further, in the Art. 3 of the Draft General Part of the Criminal Code dated June 24, 1996 the term "clear" was removed, while the rest of the text was left unchanged. However, in the Draft dated August 8, 1996 the wording of the Article 3 was changed to: "If the law does not have a definition of a committed act as a crime, it is not classified as a crime. A committed act is classified as a crime and shall be punished in accordance with laws and regulations of the Art. 10 of this Code". At the meeting held by the Legal Affairs Committee of the NPC Standing Committee in 1996, with respect to this change the participating experts agreed that the last part of the Article 3 of the Draft "A committed act is classified as a crime and shall be punished in accordance with law and the provision of the Art. 10 of this Code" is unnecessary, and proposed to remove it (Legal opinions..., 1998). Thus, the consolidation of the principle of legality in the Draft Criminal Code dated August 31, 1996 again returned to the wording of the Draft General Part of the Criminal Code dated June 24, 1996. In the Draft Criminal Code dated October 10, 1996, the standard for the principle of legality has been greatly changed in comparison with the previous version: bilateral statements of charge and acquittal have been first given, and the words "committed" have been removed. In the Art. 11 devoted to the principle of legality, it was stated: "If the law has a clear definition of a committed act as a crime, it is classified as an offense and shall be punished in accordance with the law; if the law does not have a clear definition of the act as a crime, it is not classified as a crime and shall not be punished". This wording was repeated in all the subsequent drafts of the Criminal Code, including the 1997 Criminal Code.

\section{The principle of equality of citizens before the law}

\section{(Art. 4 of the 1997 PRC Criminal Code)}

The Art. 4 of the 1997 PRC Criminal Code states: "All persons who have committed crimes are equal before the law. No one has special rights that go beyond the law" - it is in this form, in which the principle of equality of citizens before the law was established in the 1997 PRC Criminal Code.

The process of development of amendments to the Criminal Code initiated a fierce debate on the inclusion of this principle in the new Criminal Code. The opponents pointed out that the basic principles of the criminal law should be specific precisely for the criminal law, the general legal principle of equality of citizens before the law cannot be included in the Criminal Code, especially since this principle as a general legal principle is already provided for in the Constitution. In this regard, its re-consolidation in the Criminal Code is inappropriate. In turn, the supporters of the inclusion of this principle in the Criminal Code noted that it is not rational to consider a branch nature of the principle as one of the criteria for determining the basic principles of the Criminal Code. Their main reasons are as follows:

a. Correlation between the general legal principle of the socialist legality and the basic principles of various branches of law in China is the correlation of the general and the particular, 
the abstract and the concrete. General principles of law regulate and determine the content of branch principles of law. In turn, the general legal principle of legality is manifested in the branch principles. They are closely related and interdependent with each other. Without concretization in the branch principles, the general legal principle will inevitably become abstract and useless.

b. In terms of the principles of other branches of law, all the basic principles in the PRC Criminal Code and the PRC Civil Code, such as "validity and legitimacy", "equality of citizens before the law" are the manifestation of the general legal principle of socialist legality, in other words, they are particular manifestations of these general legal principles in different branches of law. Therefore, the general legal principle should not be excluded from the criminal law since it is its basic principle.

c. In terms of the real needs of legal regulation in China, despite the fact that the principle of equality of citizens before the law is already provided for in the Constitution, its direct consolidation in the Criminal Code, however, is significant due to the fact that it expresses the basic qualities and the essential spirit of the Chinese criminal law and contributes to the reduction and elimination of privileges in applying the criminal law in China's judicial practice (Zhao Bingzhi, 2004).

In the end, having adopted the above proposal, the legislator established this principle in Part 1 of Art. 60 of the Draft (in the version for discussion) for the first time: "All persons who have committed a crime are equal before the law. No privilege before the law is acceptable".

In the further discussion on the abovementioned Draft, theorists in the field of criminal law and law enforcement authorities have indicated that the basic principles of the Criminal Code are recognized by the guidelines that permeate all the criminal law standards and their application, express the basic qualities of the criminal law and its basic spirit, and play a dominant and central role in the Criminal Code; their status determines the need for their consolidation in the first chapter. It is obviously unacceptable that the principle of equality of citizens before the law permeating all areas of the criminal law and the criminal justice is placed in Paragraph 1 "Sentencing" of Chapter 4 of the General Part of the Criminal Code. It was proposed to group all the basic principles of the criminal law in Chapter 1 of the General Part of the Criminal Code. The proposal was adopted by the legislator. Accordingly, in the Draft PRC Criminal Code dated mid-December 1996, the principle of equality of citizens before the law was provided for in Art. 4 of Chapter 1 "Objectives, Basic Principles and Jurisdiction of the Criminal Code". At the same time, the appropriate adjustments of its content have been made: "No privilege before the law is acceptable" was replaced with "no one has special rights that go beyond the law".

\section{The principle of compliance of punishment with crime and criminal liability}

\section{(Art. 5 of the 1997 PRC Criminal Code)}

The Article 5 of the 1997 Criminal Code states: "A penal sanction shall be consistent with a crime committed by an offender and its criminal liability". This is the principle of compliance of punishment with crime and criminal liability.

The principle of compliance of punishment with crime and criminal liability is formed on the basis of the principle of compliance of punishment with crime. Since punishment should correspond not only with crime, but also with criminal liability, therefore, it is more appropriate to call it the principle of 
compliance of punishment with crime and criminal liability. In the development of amendments to the Criminal Code in relation to the issue of the establishment of this principle in the PRC Criminal Code there were different opinions among scholars and practitioners. Some scientists believed that the principle of compliance of punishment with crime and criminal liability is a principle of sentencing, but not the basic principle of the criminal law in general; in addition, this principle is not considered as a reason to classify a crime and sentencing, so it cannot be directly consolidated and recognized as the basic principle of the criminal law of China. Supporters, in turn, noted that the principle of compliance of punishment with crime and criminal liability is not only the principle to be followed in sentencing, but the principle that should guide the establishment of types and scope of sanctions for various crimes in the process of development of the Criminal Code. This principle does not applies to any part of the criminal law, but is the criterion that pervades the entire content of the criminal law and criminal justice. In this connection, it performs a function of the basic principle of the criminal law. Regarding the effectiveness, the principle of compliance of punishment with crime and criminal liability is not just a declaratory provision; the direct consolidation of this principle has an important and positive impact for the full implementation of the basic spirit of the criminal legislation in the criminal law itself and other criminal law standards, and it is useful for proper understanding and application of the criminal law standards in judicial practice.

Eventually, the legislator summarizing the above opinions has defined this principle for the first time in Part 2 of Art. 60 in the Draft (in the version for discussion) dated October 10, 1996 as follows: "A penal sanction shall be consistent with a crime committed by an offender and its criminal liability".

In discussing the above-mentioned Draft the legislator accepted a rational suggestion that the principle of compliance of punishment with crime and criminal liability should be provided for in Art. 5 of Chapter 1 "Objectives, Basic Principles and Jurisdiction of the Criminal Code", with a change in the order of certain words. This provision is retained in the 1997Criminal Code.

\section{Conclusion}

In the development of amendments to the Criminal Code, the specialists in the field of criminal law of China were constantly arguing about whether or not to include the new basic principles in the Criminal Code, and which principles should be included. Once the Art. 3 of the Draft General Part of the Criminal Code dated August 8, 1995 established the principle of legality for the first time, these disputes often achieved great intensity. According to some estimations, at the time, in addition to the above three basic principles, scientists and experts also offered such principles as the principle of unity of the subjective and the objective, the principle of compliance of punishment with leniency, the principle of compliance of education with correction, the principle of unity of the criminal legality, the principle of individual criminal responsibility, the principle of fairness of criminal responsibility, the principle of inevitability of punishment, the principle of humanity and the principle of individualization of punishment (Gao Mingxuan, 2012). Given the fact that all these principles relate either to sentencing or to the execution of punishment, they do not belong to the basic principles, and due to the fact that there were large differences regarding them, in the end these principles have not been adopted by the legislator. 


\section{References}

Fang, C.X. (1999). The basic principle and the criminal law values. Bulletin of the Institute for Political and Legal managers, 1.

Fen, F.L. (1999). The basic principles of criminal law in our country. Political-Legal Forum (Journal of China University of Politics and Law), 2.

Gao, M.X. (1995). On the establishment of the principle of legality in the Criminal Code of our country. Chinese jurisprudence, 5.

Gao, M.X., Zhao, B.Z. (1998). Review of documents on the Chinese criminal law. Edited by Gao, M.X., Zhao, B.Z. Beijing, Chinese People's Public Security University.

Gao, M.X. (2012). Origin, formation, development and improvement of the Chinese criminal law. Edited by Gao, M.X. Beijing: Beijing University Publishing House.

Legal opinions of experts on the Draft General Part of the PRC Criminal Code and the Draft Special Part of the PRC Criminal Code dated September 6, 1996 under the treatment of the Criminal Law Department of the Legal Affairs Committee of the NPC Standing Committee. Review of documents on the criminal law of China. Edited by Gao M.X., Zhao B.Z. Beijing, Chinese People's Public Security University, p. 2128.

Ma, K.C. (1997). On the implementation of the principle of legality in legislation. Collection of proposals for the development of amendments to the PRC Criminal Code. Edited by G. M.X. Publishing House of the Chinese People's University.

Theses of the consolidated report: ten essential problems in the process of drafting of the Criminal Code dated May 29, 1996 submitted by the Cabinet of the steering group to develop amendments to the Criminal Code of the Ministry of Public Security. Review of documents under the criminal law in the new China. V. 2. Publishing House of the Chinese People's Public Security University, 1998, p. 2653.

Zhao, B.Z. (2004). Special issues in the General Part of the Criminal Code. Legal Publishing House.

\section{Становление основных принципов в современном китайском}

\section{уголовном праве}

Пан Дунмэй ${ }^{a}$, Гао Минсюань ${ }^{0}$

${ }^{a}$ Хэйлунцзянский университет КНР, провиция Хэйлунцзян, 150080, Харбин, район Нань Ган, ул. Сюе Фу, 74

${ }^{\sigma}$ Пекинский педагогический университет КНР, 100875, Пекин, р-н Хайдянь, ул. Синьцзекоувай, 19

В cm. 3, 4, 5 Уголовного кодекса Китайской Народной Республики 1997 г. (далее - УК КНР 1997 2.) предусмотрены, соответственно, принции законности, принции равенства граждан перед законом, принцип соответствия наказания преступлению и уголовной ответственности. Эти три статьи являются новеллой УК КНР 1997 г. Формирование базовых принципов уголовного закона считается одной из основных проблем уголовного законодательства, поэтому в проиессе разработки проектов Уголовного кодекса в законодательных и судебных органах, а также среди экспертов существовали различные мнения в отношении того, нужно ли допол- 
нительно предусматривать основные принципь в УК КНР, какие основньле принцииь следует добавить, как и в какой главе УК КНР следует описать данные основные принципь, и др. Все эти вопросы и варианты их решения представлены в настоящей статье.

Ключевые слова: принципы уголовного права, принцип законности, принцип равенства граждан перед законом, приниип соответствия наказания преступлению и уголовной ответственности.

Статья подготовлена в рамках ключевого проекта национального фонда общественных наук КНР «Изучение институтов в Общей части уголовного права» (номер проекта: 16АFХ008).

Научная специиальность: 12.00.00 - юридические науки. 